\title{
Shifts in soil and plant functional diversity along an altitudinal gradient in the French Alps
}

\author{
Alexia Stokes ${ }^{1 *}$ (D) Guillermo Angeles², Fabien Anthelme ${ }^{1}$, Eduardo Aranda-Delgado ${ }^{3}$, Isabelle Barois², \\ Manon Bounous ${ }^{1}$, Nereyda Cruz-Maldonado ${ }^{1}$, Thibaud Decaëns ${ }^{4}$, Stéphane Fourtier ${ }^{1}$, \\ Grégoire T. Freschet ${ }^{5}$, Quentin Gabriac ${ }^{4}$, Daniel Hernández-Cáceres ${ }^{1}$, Leonor Jiménez², Jing Ma ${ }^{6}$, \\ Zhun Mao ${ }^{1}$, Beatriz Eugenia Marín-Castro ${ }^{7}$, Luis Merino-Martín 1,4,12, Awaz Mohamed ${ }^{1}$, Christian Piedallu \\ Carlos Pimentel-Reyes ${ }^{2}$, Hans Reijnen ${ }^{4}$, Frédérique Reverchon ${ }^{9}$, Hervé Rey ${ }^{1}$, Lavinia Selli ${ }^{1}$, \\ Christina Desireé Siebe-Grabach ${ }^{10}$, Katrin Sieron ${ }^{11}$, Monique Weemstra ${ }^{1,4}$ and Catherine Roumet $^{4}$
}

\begin{abstract}
Objectives: Altitude integrates changes in environmental conditions that determine shifts in vegetation, including temperature, precipitation, solar radiation and edaphogenetic processes. In turn, vegetation alters soil biophysical properties through litter input, root growth, microbial and macrofaunal interactions. The belowground traits of plant communities modify soil processes in different ways, but it is not known how root traits influence soil biota at the community level. We collected data to investigate how elevation affects belowground community traits and soil microbial and faunal communities. This dataset comprises data from a temperate climate in France and a twin study was performed in a tropical zone in Mexico.

Data description: The paper describes soil physical and chemical properties, climatic variables, plant community composition and species abundance, plant community traits, soil microbial functional diversity and macrofaunal abundance and diversity. Data are provided for six elevations (1400-2400 m) ranging from montane forest to alpine prairie. We focused on soil biophysical properties beneath three dominant plant species that structure local vegetation. These data are useful for understanding how shifts in vegetation communities affect belowground processes, such as water infiltration, soil aggregation and carbon storage. Data will also help researchers understand how plant communities adjust to a changing climate/environment.
\end{abstract}

Keywords: Aggregate stability, Alpine ecosystems, Carbon, Community, Elevation, Environmental gradient, Infiltration, Macroinvertebrates, Microorganisms, Plant community traits, Soil biophysical properties

\section{Objective}

Elevational gradients can be used as a space-for-time substitution to provide insights into the response of communities to climatic changes and the impact on the local environment $[1,2]$. In particular, altitude integrates changes in the diverse conditions that determine soil

\footnotetext{
*Correspondence: alexia.stokes@cirad.fr

1 AMAP, Univ Montpellier, INRAE, IRD, CIRAD, CNRS, 34000 Montpellier, France

Full list of author information is available at the end of the article
}

biophysical properties [3], including temperature, soil moisture, solar radiation and input from vegetation [4]. In an attempt to disentangle the mechanisms through which vegetation affects soil biotic and abiotic processes at different elevations, we collated data on the biophysical environment, soil physico-chemical properties, plant community traits, microbial functional diversity and soil macroinvertebrate indicators.

Soil biophysical properties are heavily influenced by input rates and decomposability of organic matter, transport to deeper soil horizons and physical protection in

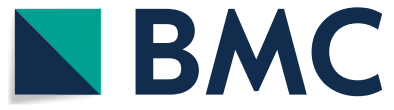

(c) The Author(s) 2021. This article is licensed under a Creative Commons Attribution 4.0 International License, which permits use, sharing, adaptation, distribution and reproduction in any medium or format, as long as you give appropriate credit to the original author(s) and the source, provide a link to the Creative Commons licence, and indicate if changes were made. The images or other third party material in this article are included in the article's Creative Commons licence, unless indicated otherwise in a credit line to the material. If material is not included in the article's Creative Commons licence and your intended use is not permitted by statutory regulation or exceeds the permitted use, you will need to obtain permission directly from the copyright holder. To view a copy of this licence, visit http://creativeco mmons.org/licenses/by/4.0/. The Creative Commons Public Domain Dedication waiver (http://creativecommons.org/publicdomain/ zero/1.0/) applies to the data made available in this article, unless otherwise stated in a credit line to the data. 
aggregate complexes. Therefore, our dataset includes data from infiltration experiments in the field and the measurement of soil aggregate stability at different depths. Our data also allow researchers to explore the impact of plant communities and soil macroinvertebrates on soil properties and vice-versa. With a particular focus on three plant species that structure local vegetation communities, belowground community-level traits were measured to determine how plant community composition impacts soil biophysics and microbial activity. To our knowledge, this dataset represents the largest freely available collection of data on plant traits and soil variables along a $1000 \mathrm{~m}$ elevational gradient in a temperate climate. Methods for each measurement are provided in the data files and supplementary materials (Table 1).

\section{Data description}

We present data collected in 2018, at six altitudes along an elevational gradient (1400-2400 m), at Massif de Belledonne, France (Table 1, file 1, [5]). Bedrock was composed of Variscan metamorphic rocks and ophiolitic complexes. Soils were umbrisols and cambisols and laminar erosion was present (Table 1, file 2, [6]). Climatic data (Table 1, file 3) were estimated over 2004-2014, using the Aurelhy model [7]. Soil water potential and temperature were measured at each altitude for two growing seasons (2018-2019, Table 1, file 4).

Five $400 \mathrm{~m}^{2}$ plots were chosen at each altitude, so that two or three dominant and community-structuring species were present: Picea abies (L.) H. Karst, Vaccinium myrtillus L. and Juniperus communis L. A botanical survey was performed in the plot (Table 1, file 5) and one adult individual of each structuring species was selected. At the limit of the individual's canopy on the downslope side, infiltration tests were performed to estimate water flow through soil [8] and hydraulic conductivity of the quasi-steady phase was calculated (Table 1, file 6). Soil samples were collected for an overall description of soil type per horizon (Table 1, file 2) and aggregate stability measurements (Table 1, file 7 [9]).

To investigate the relationships between soil biophysical properties and vegetation, plant community composition was measured in a $1.0 \mathrm{~m}^{2}$ subplot within each plot and close to each structuring species (Table 1, file 8). Rhizospheric soil attached to fine roots of the three structuring plant species was collected. A soil monolith $(0.25 \mathrm{~m} \times 0.25 \mathrm{~m} \times 0.15 \mathrm{~m}$ depth$)$ was excavated within each subplot $(n=70)$. Above the monolith, litter layer thickness (Table 1, file 9) and aboveground biomass per species were measured (Table 1, file 10).

Soil texture, cationic exchange capacity, $\mathrm{pH}$, organic carbon, nitrogen content, nitrate and ammonium were determined on pooled soil samples harvested within each monolith (Table 1, file 9). The MicroResp ${ }^{\mathrm{TM}}$ system [10] was used to characterize microbial activity and functional diversity on air-dried bulk and rhizospheric samples, through the community level physiological profiles of the soil microbial communities (Table 1, file 11).

Soil macroinvertebrates were hand sorted from each monolith and fixed in 100\% ethanol. Macroinvertebrates were identified at the order level, except for earthworms for which morphological diagnoses were combined with DNA barcoding to obtain species level assignations. Invertebrates within each taxa were counted and weighed (Table 1, file 12, [11]).

Roots were hand sorted, washed and sorted into categories according to their diameter and functionality: rhizomes, very coarse roots with diameter $>5 \mathrm{~mm}$, coarse

Table 1 Overview of data files/data sets

\begin{tabular}{|c|c|c|c|}
\hline Label & Name of data file/data set & File type (file extension) & Data repository and identifier (DOI or accession number) \\
\hline Data file 1 & Plots and map & MS Excel file (.x|sx) & Portail Data INRAE. https://doi.org/10.15454/E3SAPW (2020) [15] \\
\hline Data file 2 & Description of soil profiles & MS Excel file (.xIsx) & Portail Data INRAE. https://doi.org/10.15454/ZTCHEG (2020) [16] \\
\hline Data file 3 & Plot climate interpolated base & MS Excel file (.xIsx) & Portail Data INRAE. https://doi.org/10.15454/ZDODW2 (2020) [17] \\
\hline Data file 4 & Soil water potential 2018-2019 & MS Excel file (.xIsx) & Portail Data INRAE. https://doi.org/10.15454/PJKD06 (2020) [18] \\
\hline Data file 5 & Plot vegetation $20 \times 20 \mathrm{~m}$ & MS Excel file (.xIsx) & Portail Data INRAE. https://doi.org/10.15454/UGFNKE (2020) [19] \\
\hline Data file 6 & Stable state infiltration & MS Excel file (.xIsx) & Portail Data INRAE. https://doi.org/10.15454/PWWMYV (2020) [20] \\
\hline Data file 7 & Monolith aggregate stability & MS Excel file (.xIsx) & Portail Data INRAE. https://doi.org/10.15454/UOU4TO (2020) [21] \\
\hline Data file 8 & Monolith $1 \times 1 \mathrm{~m}$ vegetation & MS Excel file (.xlsx) & Portail Data INRAE. https://doi.org/10.15454/FZ7RA7 (2020) [22] \\
\hline Data file 9 & Ecopics soil analysis & MS Excel file (.xIsx) & Portail Data INRAE. https://doi.org/10.15454/B3FP79 (2020) [23] \\
\hline Data file 10 & Ecopics aboveground biomass & MS Excel file (.x|sx) & Portail Data INRAE. https://doi.org/10.15454/N70ZST (2020) [24] \\
\hline Data file 11 & $\begin{array}{l}\text { Ecopics community level physi- } \\
\text { ological profiles }\end{array}$ & MS Excel file (.xIsx) & Portail Data INRAE. https://doi.org/10.15454/KFBNR8 (2020) [25] \\
\hline Data file 12 & Monolith earthworms & MS Excel file (.xIsx) & Portail Data INRAE. https://doi.org/10.15454/UBFC6D (2020) [26] \\
\hline Data file 13 & Ecopics monolith root traits & MS Excel file (.xIsx) & Portail Data INRAE. https://doi.org/10.15454/RARBD1 (2020) [27] \\
\hline
\end{tabular}


roots with diameter $2-5 \mathrm{~mm}$ and fine roots $(<2 \mathrm{~mm})$. Fine roots were separated into absorptive and transport roots [12]. Two subsamples of roots $<5 \mathrm{~mm}$ were scanned and analysed using Winrhizo Pro (Regent Instruments, Canada). Several root traits were measured, including root length density and mass, diameter, specific root length and tissue density (Table 1, file 13, [13]. Chemical traits were measured on absorptive and transport roots (Table 1, file 13), including nitrogen, carbon content and hydrosoluble compounds, hemicellulose, cellulose and lignin content [14].

\section{Limitations}

Although this dataset comprises a large number of field and laboratory data collated from 70 monoliths in 30 plots, long-term climatic data were not available for each of the six altitudinal levels. Therefore we used the Aurelhy model, that estimates climatic data to a resolution of $1 \mathrm{~km}$ [7]. As some altitudinal bands were located within $1 \mathrm{~km}$ of each other, data will be the same for those plots. Also, datasets refer specifically to three dominant and community-structuring plant species, limiting generalization at larger scales.

\section{Acknowledgements \\ Thanks are due to the Mairie de Chamrousse, Isère, France, for access to field sites.}

\section{Authors' contributions}

AS prepared the manuscript. AS, GA, FA, IB, TD, GTF, LJ, ZM, BEM-C, LM-M, FR, KS, MW, CR designed and conducted fieldwork. MB, EA-D, NC-M, SF, QG, $\mathrm{DH}-\mathrm{C}, \mathrm{JM}, \mathrm{AM}, \mathrm{CPR}, \mathrm{HR}$, HRey conducted fieldwork. CDS-G designed fieldwork. MB, GTF, NC-M, QG, DH-C, LM-M, CPR, HR, LS, CR, MW, performed laboratory analyses. MB, TD, GTF, QG, DH-C, BEM-C, LM-M, AM, CP, KS, MW, CR analysed data. AS, GA, FA, IB, TD, GTF, ZM, BEM-C, LM-M, AM, FR, KS, MW, CR conceived and reviewed the final manuscript before submission. All authors read and approved the final manuscript.

\section{Funding}

Funding was provided by the French and Mexican governments (ECOPICS project, ANR-16-CE03-0009 and CONACYT-2 73659).

\section{Availability of data and materials}

The data described in this Data note can be freely and openly accessed on Portail Data INRAE under https://data.inrae.fr/dataverse/ecopics. Please see Table 1 for details and links to the data. Supplementary material can be accessed at: https://doi.org/10.15454/1S15ZS.

\section{Ethics approval and consent to participate}

Not applicable.

\section{Consent for publication}

Not applicable.

\section{Competing interests}

The authors declare that they have no competing interests.

\section{Author details}

${ }^{1}$ AMAP, Univ Montpellier, INRAE, IRD, CIRAD, CNRS, 34000 Montpellier, France.

${ }^{2}$ Red de Ecología Funcional, Instituto de Ecología, A.C., Xalapa, Veracruz, Mexico. ${ }^{3}$ Terranova Lombricultores, Coatepec, Veracruz, Mexico. ${ }^{4}$ CEFE, Univ Montpellier, CNRS, EPHE, IRD, Univ Paul Valéry Montpellier 3, Montpellier,
France. ${ }^{5}$ Station d'Ecologie Théorique et Expérimentale, CNRS, 09200 Moulis, France. ${ }^{6}$ Low Carbon Energy Institute, China University of Mining and Technology, Xuzhou 221008, China. ${ }^{7}$ Laboratorio de Edafología Ambiental, Instituto de Geología, Universidad Nacional Autónoma de México, Mexico City, Mexico. ${ }^{8}$ Université de Lorraine, AgroParisTech, INRAE, UMR Silva, Nancy, France. ${ }^{9}$ Red de Estudios Moleculares Avanzados, Instituto de Ecología, A.C., Pátzcuaro, Michoacán, Mexico. ${ }^{10}$ Laboratorio de Edafología Ambiental, Instituto de Geología, Universidad Nacional Autónoma de México, Mexico City, Mexico. ${ }^{11}$ Centro de Ciencias de la Tierra, Universidad Veracruzana, 91090 Xalapa, Veracruz, Mexico. ${ }^{12}$ Departamento de Biología y Geología, Física y Química inorg'anica, ESCET, Universidad Rey Juan Carlos, C/Tulip'an s/n, M'ostoles, 28933 Madrid, Spain.

Received: 7 November 2020 Accepted: 28 January 2021

Published online: 08 February 2021

\section{References}

1. Fukami T, Wardle DA. Long-term ecological dynamics: reciprocal insights from natural and anthropogenic gradients. Proc R Soc B Biol Sci. 2005;272:2105-15.

2. Read QD, Moorhead LC, Swenson NG, Bailey JK, Sanders NJ. Convergent effects of elevation on functional leaf traits within and among species. Funct Ecol. 2014;28:37-45.

3. Targulian VO, Krasilnikov PV. Soil system and pedogenic processes: self-organization, time scales and environmental significance. CATENA. 2007;71:373-81.

4. Körner C. The use of 'altitude' in ecological research. Tree. 2007;22:569-74.

5. Weemstra M, Freschet $G$, Stokes A, Roumet C. Patterns in intraspecific variation in root traits are species-specific along an elevation gradient. Funct Ecol. 2021; 35:342-56.

6. WRB. World Reference Base for Soil Resources 2014, update 2015, International soil classification system for naming soils and creating legends for soil maps. 2015; IUSS Working Group World Soil Resources Reports No. 106. FAO, Italy.

7. Piedallu C, Gégout JC, Lebourgeois F, Seynave I. Soil aeration, water deficit, nitrogen availability, acidity and temperature all contribute to shaping tree species distribution in temperate forests. J Veg Sci. 2016;27:387-99.

8. Marín-Castro BE, Negrete-Yankelevich S, Geissert D. Litter thickness, but not root biomass, explains the average and spatial structure of soil hydraulic conductivity in secondary forests and coffee agroecosystems in Veracruz, Mexico. Sci Tot Environ. 2017;607-608:1357-66.

9. Le Bissonnais Y. Aggregate stability and assessment of soil crustability and erodibility: I. Theory and methodology. Eur J Soil Sci. 1996;47:425-37.

10. Campbell CD, Chapman SJ, Cameron CM, Davidson MS, Potts JM. A rapid microtiter plate method to measure carbon dioxide evolved from carbon substrate amendments so as to determine the physiological profiles of soil microbial communities by using whole soil. Appl Environ Microbiol. 2003;69:3593-9.

11. Anderson JM, Ingram JSI. Tropical soil biology and fertility. In: A handbook of methods. 2nd edn. UK: CAB International; 1993.

12. Freschet GT, Roumet $C$, Comas LH, Weemstra M, Bengough AG, Rewald B, Bardgett RD, De Deyn GB, Johnson D, Klimešová J, Lukac M, McCormack L, Meier IC, Pagès L, Poorter H, Prieto I, Wurzburger N, Zadworny M, Bagniewska-Zadworna A, Blancaflor EB, Brunner I, Gessler A, Hobbie SE, Iversen CM, Mommer L, Picon-Cochard C, Postma JA, Rose L, Ryser P, Scherer-Lorenzen M, Soudzilovskaia NA, Sun T, Valverde-Barrantes OJ, Weigelt A, York LA, Stokes A. Root traits as drivers of plant and ecosystem functioning: current understanding, pitfalls and future research needs. New Phytol. 2021. https://doi.org/10.1111/nph.17072.

13. Freschet GT, Pagès $L$, Iversen $C M$, Comas LH, Rewald $B$, Roumet $C$, Klimešová J, Zadworny M, Poorter H, Postma JA, Adams TS, BagniewskaZadworna A, Blancaflor EB, Brunner I, Cornelissen JHC, Garnier E, Gessler A, Hobbie SE, Lambers H, Meier IC, Mommer L, Picon-Cochard C, Rose L, Ryser P, Scherer-Lorenzen M, Soudzilovskaia NA, Stokes A, Sun T, Valverde-Barrantes OJ, Weemstra M, Weigelt A, Wurzburger N, York LM, Batterman SA, Bengough AG, Gomes de Moraes M, Janeček Š, Salmon V, Tharayil N, McCormack ML. A starting guide to root ecology: strengthening ecological concepts and standardizing root classification, sampling, 
processing and trait measurements. New Phytologist. 2020; Accepted. \{hal-02918834\}.

14. Van Soest PJ. Use of detergents in the analysis of fibrous feeds. II A rapid method for the determination of fiber and lignin. Off Agric Chem. 1963:46:829.

15. Sieron K. Ecopics plots and map. Portail Data INRAE. https://doi. org/10.15454/E3SAPW. 2020

16. Marin Castro BE. Description of soil profiles. Portail Data INRAE. https:// doi.org/10.15454/ZTCHEG. 2020

17. Piedallu C. Plot climate interpolated base. Portail Data INRAE. https://doi. org/10.15454/ZDODW2. 2020

18. Merino-Martin L, Mohamed A. Soil water potential 2018-2019. Portail Data INRAE. https://doi.org/10.15454/PJKD06. 2020

19. Bounous M, Anthelme F. Plot Vegetation $20 \times 20$ m. Portail Data INRAE. https://doi.org/10.15454/UGFNKE. 2020

20. Stokes A. Stable state infiltration. Portail Data INRAE. https://doi. org/10.15454/PWWMYV. 2020

21. Merino-Martin L. Monolith aggregate stability. Portail Data INRAE. https:// doi.org/10.15454/UOU4TO. 2020
22. Bounous $M$, Anthelme F. Monolith $1 \times 1 \mathrm{~m}$ vegetation. Portail Data INRAE. https://doi.org/10.15454/FZ7RA7. 2020

23. Stokes A. Soil analysis. Portail Data INRAE. https://doi.org/10.15454/B3FP7 9. 2020

24. Roumet C. Monolith aboveground biomass. Portail Data INRAE. https:// doi.org/10.15454/N70ZST. 2020

25. Hernández-Cáceres D. Microbial community level physiological profiles. Portail Data INRAE. https://doi.org/10.15454/KFBNR8. 2020

26. Decaëns T. Monolith earthworms. Portail Data INRAE. https://doi. org/10.15454/UBFC6D. 2020

27. Roumet C. Monolith root traits. Portail Data INRAE. https://doi. org/10.15454/RARBD1. 2020

\section{Publisher's Note}

Springer Nature remains neutral with regard to jurisdictional claims in published maps and institutional affiliations.
Ready to submit your research? Choose BMC and benefit from:

- fast, convenient online submission

- thorough peer review by experienced researchers in your field

- rapid publication on acceptance

- support for research data, including large and complex data types

- gold Open Access which fosters wider collaboration and increased citations

- maximum visibility for your research: over $100 \mathrm{M}$ website views per year

At $\mathrm{BMC}$, research is always in progress.

Learn more biomedcentral.com/submissions 